\title{
Supplement to: Parallel between the isotopic composition of coccolith calcite and carbon levels across Termination II: Developing a new paleo-CO $\mathrm{C}_{2}$ probe
}

Camille Godbillot ${ }^{1}$, Fabrice Minoletti ${ }^{1}$, Franck Bassinot ${ }^{2}$, Michaël Hermoso $^{3}$

${ }^{1}$ Institut des Sciences de la Terre de Paris (UMR 7193 ISTeP), CNRS, Sorbonne Université, 75005 Paris, 5 France

${ }^{2}$ Laboratoire des Sciences de l'Environnement et du Climat (UMR 8212 LSCE), CEA, CNRS, Université Versailles Saint Quentin, 91191, Gif sur Yvette, France

${ }^{3}$ Laboratoire d'Océanologie et de Géosciences (UMR 8187 LOG), Université du Littoral Côte d'Opale, CNRS, Université de Lille, 62930 Wimereux, France

10 Correspondence to: Camille Godbillot (camille.godbillot@sorbonne-universite.fr) 


\section{Age model for site MD95-2037 over Termination II}

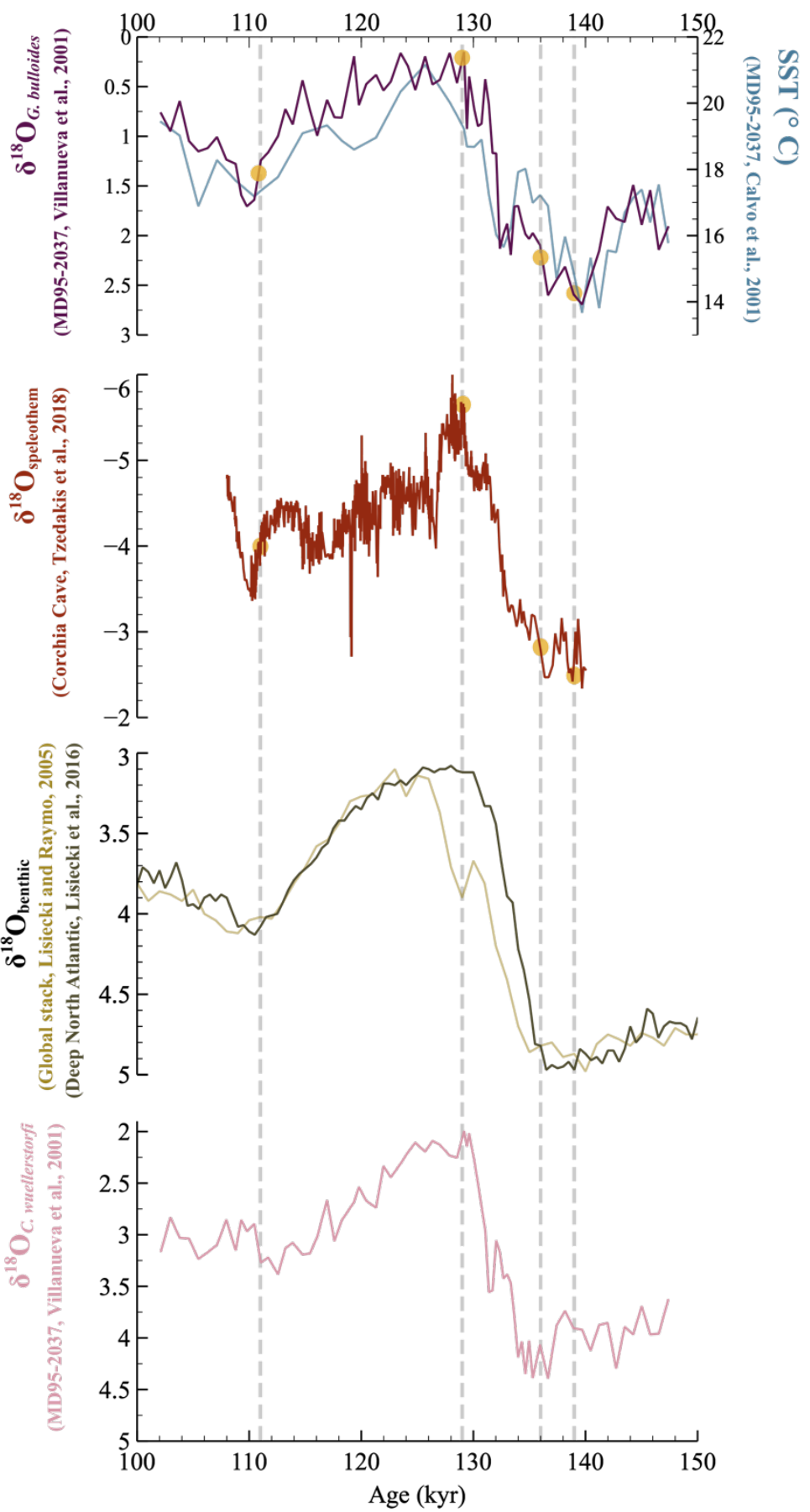

Figure S1: Synchronizing the MD95-2037 Termination II $\delta^{\mathbf{1 8}} \mathbf{O}_{\text {planktonic }}$ record with speleothem $\delta^{18}$ O records. We first aligned the 15 Cibidoides wullerstorfi $\delta^{18} \mathrm{O}$ signal of site MD95-2037 (Villanueva et al., 2001) to the Regional Deep North Atlantic $\delta^{18} \mathrm{O}$ Benthic Stack (Lisiecki and Stern, 2016) for the first order trends. The age model around Termination II was refined by aligning the $\delta^{18} \mathrm{O}_{\text {bulloides }}$ signal of site MD95-2037 (Villanueva et al., 2001) to the Corchia Cave composite speleothem $\delta^{18} \mathrm{O}$ record (Tzedakis et al., 2018). Tie-points are represented as yellow dots. For comparison, we also included the Global Benthic $\delta^{18} \mathrm{O}$ Stack (Lisiecki and Raymo, 2005) and SST records for the site (Calvo et al., 2001). 


\section{Fraction composition and preservation}
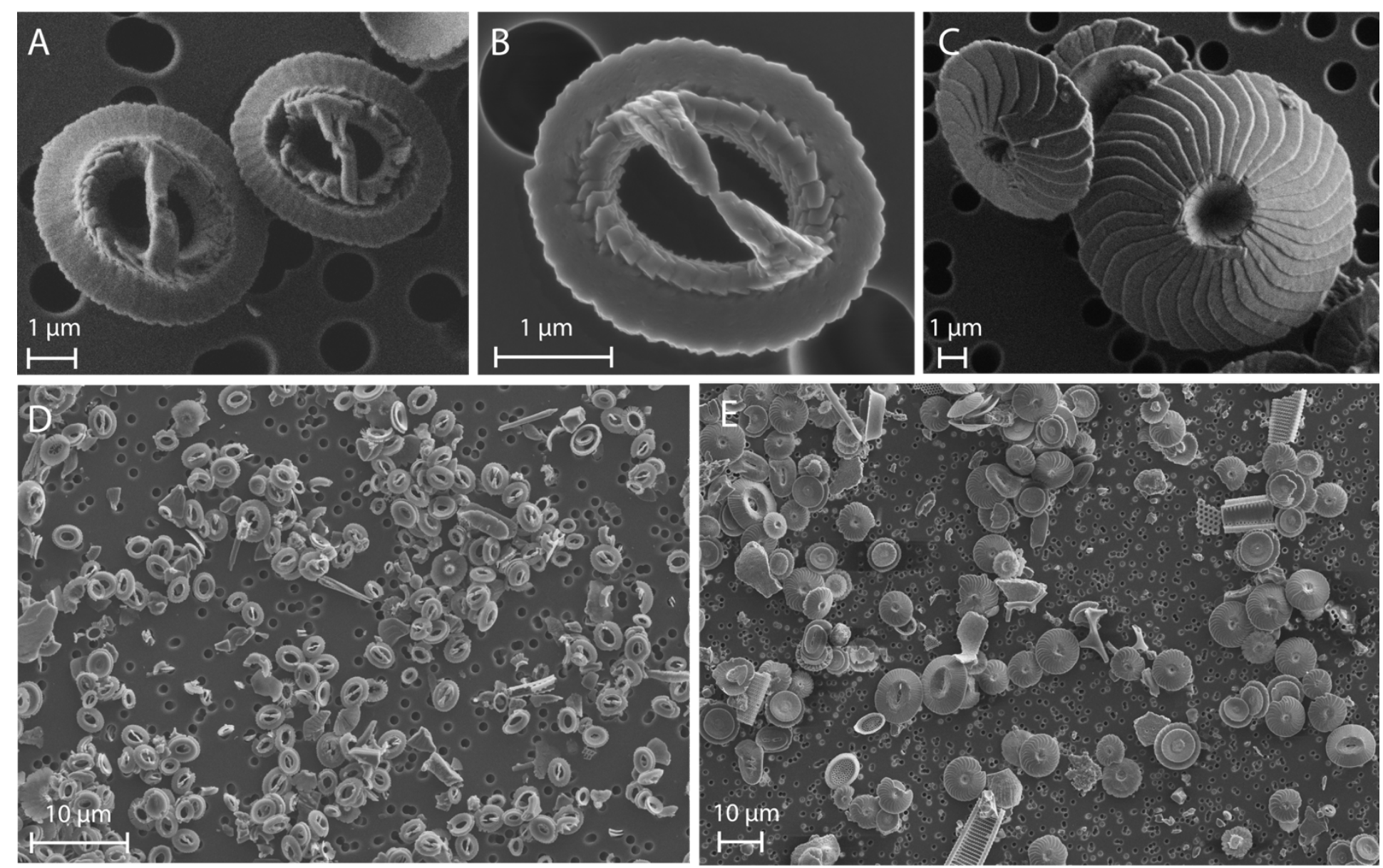

Figure S2: Coccolith close-ups and general views of the purified coccolith assemblages obtained for core MD95-2037 sediments. A: Gephyrocapsa sp. coccoliths at 123.5 kyrs (Interglacial). B: Gephyrocapsa sp. coccolith at 139.7 kyrs (Glacial). C: Calcidiscus sp. coccoliths at 123.5 kyrs (Interglacial). D: Gephyrocapsa-dominated 2-3 $\mu \mathrm{m}$ fraction at $110.5 \mathrm{kyrs}$ (Last Glacial Inception). E: Calcidiscus-dominated 5-8 $\mu \mathrm{m}$ fraction at 135.9 lyrs (Glacial Maximum). Images were obtained using the SEM at the ISTeP Lab. The coccoliths exhibit slight etching, but no notable calcite overgrowth. The silicic material observed in the assemblages does not contribute to the isotopic signal measured on the sediment fractions. 


\section{Data used for the Miocene-to-present differential vital effect-CO 2 curve}

30 Published literature provides other examples of the forcing of $\mathrm{CO}_{2}$ on differential coccolith vital effects. We selected the datasets that provided a differential vital effect between coccolith size classes with similar diameters to those studied in this manuscript. These values are compared to the corresponding $\mathrm{pCO}_{2}$ records available for the time period. These are translated, using the SST records available for the core location, and a salinity of $33 \mathrm{psu}$, into concentrations of aqueous $\mathrm{CO}_{2}$, via the "seacarb" package in

35 R (https:// CRAN.R-project.org/package=seacarb). Error estimates (1SD) for $\left[\mathrm{CO}_{2}\right]$ were obtained by running 10,000 Monte Carlo simulations with the following uncertainties: Miocene/Pliocene $\mathrm{pCO}_{2} \pm 50$ ppm (Zhang et al., 2013), pre-industrial $\mathrm{pCO}_{2} \pm 10 \mathrm{ppm}$ to account for age uncertainties on core-top material, alkenone-derived SSTs $\pm 1.2^{\circ} \mathrm{C}$ (Conte et al., 2006), and a conservative estimate of salinity of $\pm 1 \mathrm{psu}$. We listed below the published datasets used to study the response of coccolith differential vital

40 effects to aqueous $\mathrm{CO}_{2}$ changes since the Miocene:

Table S1: Datasets used to compare the evolution of coccolith differential vital effects and aqueous $\mathrm{CO}_{2}$ changes since the Miocene.

\begin{tabular}{|c|c|c|c|c|c|}
\hline $\begin{array}{c}\text { Differential vital effect } \\
\text { datasets }\end{array}$ & Fraction size and composition & $\begin{array}{c}\text { Period, Site } \\
\text { location }\end{array}$ & $\mathrm{pCO}_{2}$ data & SST data & $\begin{array}{l}\text { Site location } \\
\text { for SST data }\end{array}$ \\
\hline Bolton and Stoll, 2013 & $\begin{array}{l}\text { 2-4 } \mu \mathrm{m} \text { (Reticulofenestra } \text { sp.-rich) } \\
\text { and } \\
6-9 \mu \mathrm{m} \text { (Helicosphaera } \text { sp.-rich) }\end{array}$ & $\begin{array}{c}\text { Pliocene, ODP site } \\
999 \text { (Caribbean) }\end{array}$ & $\begin{array}{l}\text { Zhang et al., } \\
2013\end{array}$ & $\begin{array}{l}\text { Seki et al., } 2010 \\
\text { Alkenone-Uk' }\end{array}$ & $\begin{array}{c}\text { Same as core } \\
\text { location }\end{array}$ \\
\hline Bolton and Stoll, 2013 & $\begin{array}{c}2-5 \mu \mathrm{m} \text { (rich in small } \\
\text { reticulofenestrids) and } \\
7-9 \mu \mathrm{m} \text { (rich in reticulofenestrids) }\end{array}$ & $\begin{array}{l}\text { Miocene-Pliocene, } \\
\text { site } 1088 \text { (South } \\
\text { Atlantic) }\end{array}$ & $\begin{array}{l}\text { Zhang et al., } \\
2013\end{array}$ & $\begin{array}{l}\text { Herbert et al., } \\
2016 \text { Alkenone- } \\
\text { Uk' }\end{array}$ & $\begin{array}{c}\text { Same as core } \\
\text { location }\end{array}$ \\
\hline $\begin{array}{l}\text { Candelier et al., } 2013 \\
\text { (large fraction); } \\
\text { Hermoso et al., } 2015 \\
\text { (small fraction) }\end{array}$ & $\begin{array}{c}2-3 \mu \mathrm{m} \text { (Gephyrocapsa sp.-rich) } \\
\text { and 5-8 } \mu \mathrm{m} \text { (Calcidiscus } \\
\text { leptoporus-rich) }\end{array}$ & $\begin{array}{l}\text { Core-top (North } \\
\text { Atlantic, Western } \\
\text { Indian Ocean) }\end{array}$ & $\begin{array}{l}\text { Pre-industrial } \\
280 \mathrm{ppm} \\
\text { value }\end{array}$ & $\begin{array}{l}\text { Hermoso et al., } \\
\text { 2015, from } \\
\text { WOA13 }\end{array}$ & $\begin{array}{c}\text { Same as core } \\
\text { location }\end{array}$ \\
\hline
\end{tabular}




\section{Controls on coccolith differential vital effects}
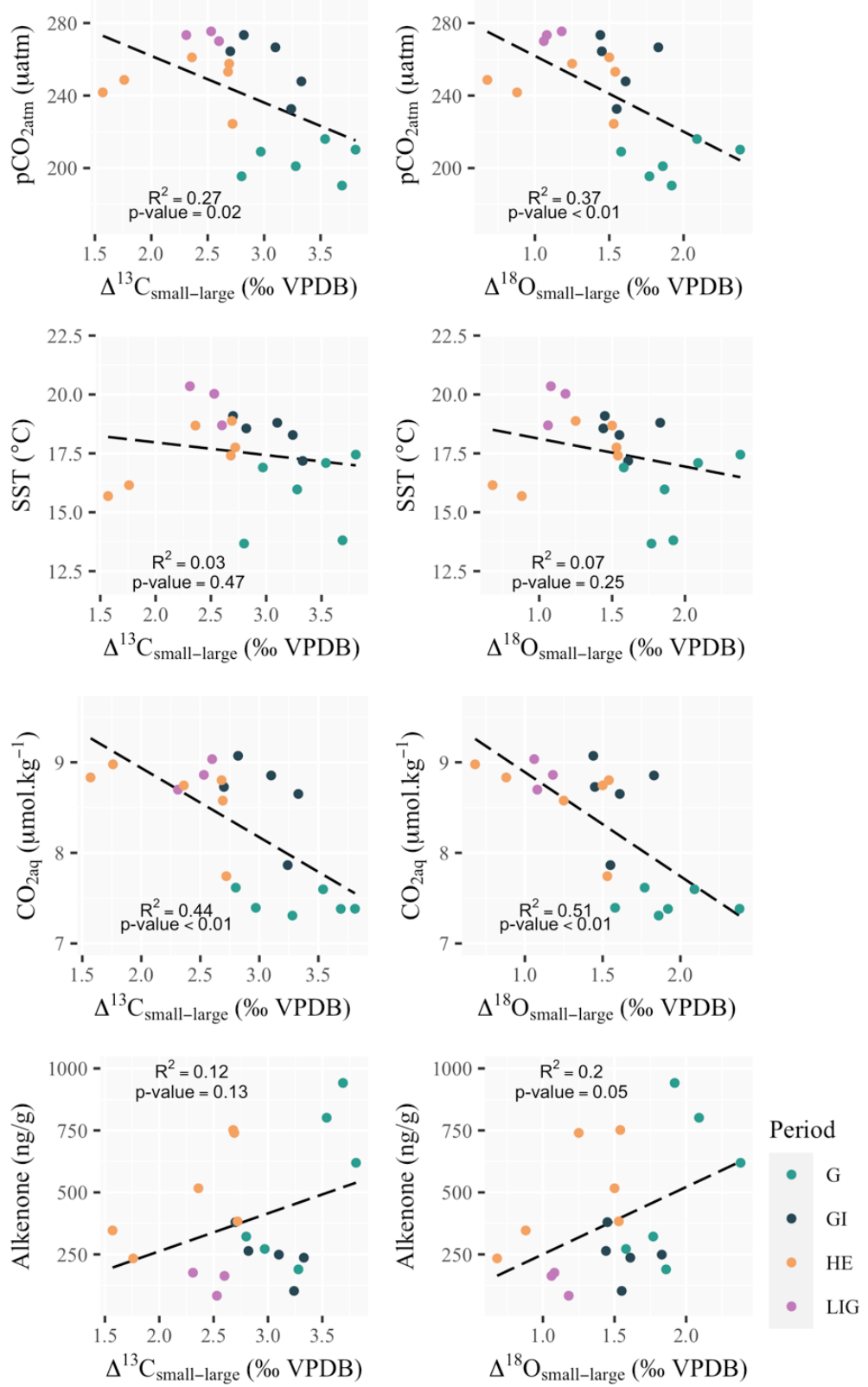

Figure S3: Environmental controls on coccolith differential vital effects. Data points are coloured according to the time period considered: The Glacial Maximum (green), Heinrich Event 11 (orange), the Last Interglacial (pink) and the Glacial Inception (dark blue). Ice core $\mathrm{pCO}_{2}$ data is from Bereiter et al., 2015, Sea surface temperature (SST) data are from Calvo et al., 2001 for site MD95-2037, and alkenone concentrations are from Villanueva et al., 2001 for site MD95-2037. 


\section{Supplementary references}

Bereiter, B., Eggleston, S., Schmitt, J., Nehrbass-Ahles, C., Stocker, T. F., Fischer, H., Kipfstuhl, S., and Chappellaz, J.: Revision of the EPICA Dome C CO2 record from 800 to 600 kyr before present, Geophys. Res. Lett., 42, 542-549, https://doi.org/10.1002/2014GL061957, 2015.

55 Bolton, C. T. and Stoll, H. M.: Late Miocene threshold response of marine algae to carbon dioxide limitation, Nature, 500, 558-562, https://doi.org/10.1038/nature12448, 2013.

Calvo, E., Villanueva, J., Grimalt, J. O., Boelaert, A., and Labeyrie, L.: New insights into the glacial latitudinal temperature gradients in the North Atlantic. Results from U37K' sea surface temperatures and terrigenous inputs, Earth Planet. Sci. Lett., 188, 509-519, https://doi.org/10.1016/S0012-

$60821 \mathrm{X}(01) 00316-8,2001$.

Candelier, Y., Minoletti, F., Probert, I., and Hermoso, M.: Temperature dependence of oxygen isotope fractionation in coccolith calcite: A culture and core top calibration of the genus Calcidiscus, Geochim. Cosmochim. Acta, 100, 264-281, https://doi.org/10.1016/j.gca.2012.09.040, 2013.

Conte, M. H., Sicre, M. A., Rühlemann, C., Weber, J. C., Schulte, S., Schulz-Bull, D., and Blanz, T.:

65 Global temperature calibration of the alkenone unsaturation index (U 37k) in surface waters and comparison with surface sediments, Geochemistry, Geophys. Geosystems, 7, https://doi.org/10.1029/2005GC001054, 2006.

Herbert, T. D., Lawrence, K. T., Tzanova, A., Peterson, L. C., Caballero-Gill, R., and Kelly, C. S.: Late Miocene global cooling and the rise of modern ecosystems, Nat. Geosci., 9, 843-847,

70 https://doi.org/10.1038/ngeo2813, 2016.

Hermoso, M., Candelier, Y., Browning, T. J., and Minoletti, F.: Environmental control of the isotopic composition of subfossil coccolith calcite: Are laboratory culture data transferable to the natural environment?, 7, 35-42, https://doi.org/10.1016/j.grj.2015.05.002, 2015.

Lisiecki, L. E. and Raymo, M. E.: A Pliocene-Pleistocene stack of 57 globally distributed benthic $\delta 18$

75 O records, Paleoceanography, 20, 1-17, https://doi.org/10.1029/2004PA001071, 2005.

Lisiecki, L. E. and Stern, J. V: Regional and global benthic $\delta 18 \mathrm{O}$ stacks for the last glacial cycle, Paleoceanography, 31, 1368-1394, https://doi.org/10.1002/2016PA003002, 2016.

Seki, O., Foster, G. L., Schmidt, D. N., Mackensen, A., Kawamura, K., and Pancost, R. D.: Alkenone and boron-based Pliocene pCO2 records, Earth Planet. Sci. Lett., 292, 201-211,

80 https://doi.org/10.1016/j.eps1.2010.01.037, 2010.

Tzedakis, P. C., Drysdale, R. N., Margari, V., Skinner, L. C., Menviel, L., Rhodes, R. H., Taschetto, A. S., Hodell, D. A., Crowhurst, S. J., Hellstrom, J. C., Fallick, A. E., Grimalt, J. O., McManus, J. F., Martrat, B., Mokeddem, Z., Parrenin, F., Regattieri, E., Roe, K., and Zanchetta, G.: Enhanced climate instability in the North Atlantic and southern Europe during the Last Interglacial, Nat. Commun., 9,

85 https://doi.org/10.1038/s41467-018-06683-3, 2018.

Villanueva, J., Calvo, E., Pelejero, C., Grimalt, J. O., Boelaert, A., and Labeyrie, L.: A latitudinal 
productivity band in the Central North Atlantic over the last 270 kyr: An alkelone perspective, Paleoceanography, 16, 617-626, https://doi.org/10.1029/2000PA000543, 2001.

Zhang, Y. G., Pagani, M., Liu, Z., Bohaty, S. M., and DeConto, R.: A 40-million-year history of

90 atmospheric CO 2, Philos. Trans. R. Soc. A Math. Phys. Eng. Sci., 371, 20130096, https://doi.org/10.1098/rsta.2013.0096, 2013. 